\title{
Seis suspiros en la literatura clásica española
}

\section{Six Sights in the Spanish Classical Literature}

\author{
Javier García Gibert \\ Universidad de Valencia \\ javier.garcia-gibert@uv.es
}

\section{RESUMEN}

El artículo acomete el análisis de seis «suspiros» estratégicamente seleccionados entre textos poéticos y narrativos importantes de la literatura clásica española (el Cid, el Romancero, el Abencerraje, Garcilaso, el Quijote, el Persiles). Atendiendo a factores textuales y contextuales, estrictamente literarios y ampliamente culturales, el análisis de esos suspiros muestra la relevancia de los mismos dentro de las obras en las que aparecen, así como sus implicaciones a diversos niveles, demostrando en último término el talento de los escritores que los han recreado.

Palabras Clave: Suspiros; poesía amorosa; neoplatonismo; Cid; Romancero; Abencerraje; novela morisca; Cervantes; melancolía.

\begin{abstract}
The article analyses six strategic «sighs» selected from major poetic and narrative texts of the Spanish classical literature (the Cid, the Romancero, the Abencerraje, Garcilaso, Don Qixote, the Persiles). Attending textual and contextual factors, strictly literary and broadly cultural, the analyse of those six sighs shows their relevance in the works in which they appear, and their implications at various levels, ultimately demonstrating the talent of the writers who created them.
\end{abstract}

Key words: Sighs; Love Poetry; Neoplatonism; Cid; Romancero; Abencerraje; Moorish novel; Cervantes; Melancholy.

Suspiro: «Aspiración fuerte y prolongada seguida de una espiración, acompañada a veces de un gemido, y que suele denotar pena, ansia o deseo». Tal es la definición de la RAE, muy descriptiva en su primera parte y bastante precisa al final de la misma en las emociones que suele transmitir esta manifestación de la expresividad humana. Por lo común, el suspiro responde, en efecto, a un desajuste entre el deseo y la realidad, y a menudo es un síntoma de melancolía: a la princesa que espera en su «jaula de oro» a su príncipe azul, sin saber si llegará o no llegará, «los suspiros se escapan de su boca de fresa». Claro. La nostalgia por el bien perdido, el anhelo por lo imposible o aún no logrado, el aba-

Copyright: (C) 2016 CSIC. Este es un artículo de acceso abierto distribuido bajo los términos de una licencia de uso y distribución Creative Commons Attribution (CC-by) España 3.0. 
timiento del ánimo por la contrariedad de la vida, son el caldo de cultivo del suspiro, aunque las fuentes del suspirar no se agotan con eso. Pues ¿quién puede negar que también hay suspiros de satisfacción y de alivio? El suspiro es, en último término, un signo ambiguo y polivalente, que hay que interpretar en cada caso. Habitualmente es una efusión discreta y delicada ${ }^{1}$, que por lo demás traduce con veracidad las aflicciones anímicas. Pero eso no es óbice para que pueda encarnarse en estados o individuos fuertemente sensuales (pocas heroínas más suspirantes que la Niña Chole que seduce al Marqués de Bradomín en la Sonata de estío valleinclanesca) y puede ser teatral e insincera como cualquier otra manifestación externa. Ya se decía en el Libro de buen amor cuando Doña Venus aleccionaba al protagonista sobre los medios de seducción: «non olvides los sospiros, en esto sey engañoso» (627c).

Esta apertura significacional de muchos suspiros es lo que nos los hace tan sugestivos en la literatura, donde es preciso acudir al contexto (y a veces no sólo literario, sino extraliterario o ampliamente cultural) para deshacer su natural ambigüedad. Es el suspiro, por lo tanto, una ocasión magnífica para la exégesis crítica, siempre que recaiga, claro está, en textos realizados por autores con talento, y no sean los suspiros esas vulgares manifestaciones de mala literatura que Céline calificaba de «bidet lyrique» ${ }^{2}$. En la selección de suspiros del presente trabajo nos ceñiremos tan sólo a algunos ejemplos de la literatura «clásica» española, entendiendo por tal, en sentido amplio, la literatura anterior a la denominada «moderna», que en este asunto tendría por cierto como uno de sus primeros y obligados referentes a ese Gustavo Adolfo Bécquer que en su rima IV encontraba en las almas que suspiran una de las fuentes mismas de la poesía («mientras responda el labio suspirando / al labio que suspira») y que en la rima XXIII creó, sin duda alguna, la reticencia más suspirante de la poesía española: «por un beso..., ¡yo no sé / qué te diera por un beso!» (donde el suspiro casi se impone al llegar a los puntos suspensivos). Y fue Bécquer precisamente quien encarnó en su día el tipo de poesía que el grandilocuente Núñez de Arce, su contemporáneo, denominaba despectivamente «suspirillos germánicos», por considerarlos leves e intrascendentes minucias poéticas venidas de las brumas septentrionales. Pronto se supo de la importancia de aquellas minucias para nuestra poesía. Pues bien, parafraseando los

${ }^{1}$ En el episodio de Paolo y Francesca de la Divina comedia se refleja muy bien esta condición discreta y espiritual de los suspiros cuando el personaje de Dante le pregunta a Francesca cómo y por qué se pasó de los dulces suspiros a los turbios deseos adulterinos («Ma dimmi: al tempo de'dolci sospiri, / a che e come concedette amore / che conosceste i dubbiosi disiri?», «Infierno», V, vv. 118-120).

${ }^{2}$ Así lo consideraba en su texto Bagatelas para una masacre, de 1937. Louis-Ferdinand Céline podría considerarse como uno de los más grandes fustigadores del suspiro literario, y denunció repetidamente el vulgar y obsceno sentimentalismo de esos suspiros tan comunes desde el Renacimiento en la tradición amorosa, y lo que tenían de falsificación sentimental en su mendaz ennoblecimiento de la pasión carnal. 
términos, que no la intención, de Núñez de Arce, examinaremos nosotros en las páginas que siguen algunos antiguos «suspirillos hispánicos»—«suspiros de España», si quiere decirse de modo más castizo y más coplero—, que, por su significado textual o contextual, literario o cultural, merecen a nuestro juicio un comentario.

Como no podía ser menos, nuestra elección de los suspiros es subjetiva y en buena parte aleatoria, aunque aspiramos a que al final del artículo se considere al menos la idoneidad de los suspiros elegidos para formar parte de una imaginada y más numerosa antología «canónica» — por así decirlo- de suspiros con enjundia en la literatura española. De la media docena de suspiros -o, más exactamente de suspiradores - que se ha seleccionado, tres se producen en contextos poéticos y otros tres en contextos narrativos, tres son de autores anónimos y el resto de autor conocido, pero todos aparecen en obras de primer nivel. En último término, lo que pretendemos es demostrar el talento de los creadores de esos suspiros: sus autores literarios. Ellos son los que han sido capaces de desrutinizar al convencional suspiro, que en manos menos sabias puede convertirse en un signo tópico y trivial, dotándolo de un valor singular como estimulador de la acción, configurador del relato o desvelador de la personalidad de quien lo emite o de quien lo contempla. Esos escritores, como veremos, han tenido el arte de fabricar situaciones en las que, aprovechando la condición del suspiro como paralenguaje ambiguo pero universal, han desvelado en sus relatos poéticos o narrativos apuntes muy sugestivos de carácter social, cultural o psicológico sobre la naturaleza humana. Acudamos ya sin más preámbulo a los suspiros en cuestión.

\section{LOS LENITIVOS SUSPIROS DEL CID}

En la cronología de la literatura española tardaremos apenas unos segundos en topar con un suspiro que merezca nuestra atención, pues este se encuentra en lo que se considera, a despecho de los poemillas mozárabes que denominamos jarchas, la página inaugural de la literatura española: es decir, aquella que abre, perdida la hoja inicial, el Poema de Mio Cid en el único manuscrito conservado de la obra. Analicemos el contexto preciso de ese primicial suspiro cidiano.

La hoja inicial perdida daría cuenta de los motivos del destierro del Cid por mandato del rey Alfonso VI, pero, como se sabe, el primer verso del texto conservado nos ofrece la imagen del héroe llorando ${ }^{3}$ :

$\begin{array}{lc}\text { De los sos ojos } & \text { tan fuertemientre llorando } \\ \text { tornava la cabeça } & \text { y estávalos catando. }\end{array}$

${ }^{3}$ Usaremos la edición de Alberto Montaner (2011). 


\begin{abstract}
Vio puertas abiertas e uços sin cañados, alcándaras vazías, sin pielles e sin mantos e sin falcones e sin adtores mudados.
\end{abstract}

La desaparición de los versos iniciales de la obra original provoca, en efecto, la circunstancia impactante de un héroe llorando como apertura del texto, algo que, indudablemente, no estaba en la intención del autor, y algo que también, por añadidura, puede extrañar a los lectores actuales del Poema, sobre todo si no están familiarizados con la literatura de la época. Es bueno advertir, por tanto, que en la épica medieval el llanto del héroe no se consideraba impropio, pues se aceptaba sin reserva alguna como un signo natural y espontáneo de sus intensas emociones ${ }^{4}$. En la Chanson de Roland, sin ir más lejos, muchos «nobles caballeros» vierten lágrimas en bloque y repetidas veces, y el propio Roldán llora y clama ante la muerte de su querido Oliveros (vv. 202223). Y ello ocurre también en otros géneros de la literatura medieval.

Al Cid, por su parte, no le faltan motivos para la angustia: súbita e injustamente ha sido desposeído de todos sus honores y de todos sus bienes, y ahora es expulsado de su tierra, dejando en la deshonra a su familia y en la pobreza a sus fieles vasallos. Pero el momento que le mueve al llanto, a tenor del Poema, es el instante preciso en que, al partir hacia su exilio, echa un postrer vistazo a su tierra natal de Bivar, de la que hasta entonces era señor y a la que ya nunca regresará. Con la cabeza vuelta hacia lo perdido, el héroe cata —es decir, «mira»- por última vez sus posesiones, referenciadas por ese enclítico «-los» del verso segundo, que remite a elementos mencionados en la hoja anterior y con el que el autor debe aludir a los palacios o los aposentos que habían constituido su hogar hasta entonces y que aparecen de pronto, como se dice después, vacíos y desolados, sin los objetos y animales que les daban calor y vida. Es la mirada sentimental de la despedida última, donde se juntan de golpe todos sus recuerdos y emociones.

Pero, a renglón seguido $-\mathrm{y}$ aquí aparece el verdadero objeto de nuestro análisis: el suspiro del Cid-, nos dice el poeta los versos siguientes:

Sospiró mio Cid ca mucho avié grandes cuidados,
fabló mio Cid bien e tan mesurado:
¿Grado a ti, Señor, Padre que estás en alto!
¡Esto me an vuelto mios enemigos malos!-

Atendiendo al contexto de los versos anteriores y posteriores, el suspiro del Cid en ese instante (el sexto verso del texto conservado) es ya el primer elemento significativo - y más todavía: un elemento «clave»— para la caracterización del personaje. El suspiro, ciertamente, desempeña aquí la función precisa de llenar los pulmones y acabar con el llanto, cumpliendo así una

\footnotetext{
${ }^{4}$ Véase a este respecto el clásico estudio, Beszard (1903).
} 
funcionalidad distinta, y aun opuesta, a la habitual ${ }^{5}$. Es decir, en este caso el suspiro - motivado, es verdad, por los «grandes cuidados» (= preocupaciones) que asolan su alma - no hay que entenderlo sólo como efecto o manifestación de abatimiento, sino a la vez y, sobre todo, como signo de control, de autodominio, tal como se muestra por lo que se dice en el siguiente verso, donde el héroe doliente es capaz ya de hablar «bien e tan mesurado». El suspiro del Cid nos da, pues, la pauta de uno de los rasgos más sobresalientes de su personalidad: la extraordinaria capacidad de supervivencia, de sobreponerse con rapidez a las más crueles adversidades.

Y ello — como es costumbre en el Poema - sin perder de vista en ningún momento la verosimilitud realista de los gestos y de las acciones. En realidad, la rápida transición del llanto a la mesura por intermedio del suspiro resulta creíble, porque el llanto inicial no era una expresión de dolor descontrolada, sino una mera efusión de lágrimas. Eso es lo que, por cierto, nos sugería el pleonasmo del verso 1: llorando «de los sus ojos». Además de ser un cliché formulario que se extendió en la poesía medieval española, proveniente al parecer de la épica francesa, dicho pleonasmo solía albergar muy concretos rasgos significacionales, como recuerda Alberto Montaner en su edición citada de la obra: «La frase, que actualmente puede parecer redundante, implicaba en la Edad Media que el llanto se reducía a las lágrimas, sin el acompañamiento, entonces habitual, de sollozos, voces y gestos» (2011: 5 y 646). Y no se piense que esta indiscreta dramatización del llanto era inhabitual, incluso entre los propios héroes o personajes distinguidos. Recuérdese sólo cómo reacciona Carlomagno ante la muerte de Roldán, arrancándose los pelos de la cabeza y estirando su barba mientras se anega en la desesperación y el llanto (Chanson de Roland, CCVI-CCX).

La actitud del Cid es muy distinta y podría incluso relacionarse con lo establecido por una tradición tan continente como la estoica. Séneca admitía, en efecto, que, ante la cruel desgracia, el sabio desahogase en lágrimas la emoción primera (primum impetum), pero esas primeras lágrimas, mediante las cuales se evaporaba (despumaverit) la parte más aguda del dolor y el sentimiento, habían de ser vertidas con una moderación a la que no le faltara ni humanidad ni dignidad (nec humanitas nec dignitas deesset) ${ }^{6}$. $\mathrm{O}$, como dice sentenciosamente el propio Séneca en otro lugar ${ }^{7}$ : lacrimandum est, non plorandum; esto es: las lágrimas son posibles, pero no el desesperado llanto. Eso es, ni más ni menos, lo que hace el Cid, y con ello demuestra, ya desde esta página inicial ese rasgo de mesura que lo caracteriza hasta el final del Poema

\footnotetext{
${ }^{5}$ Que era más bien la de dar inicio al llanto. Véase un ejemplo célebre y característico: «Aquí dio fin a su cantar Salicio, / y sospirando en el postrer acento, / soltó de llanto una profunda vena» (Garcilaso, Égloga I, vv. 225-227).

${ }^{6}$ Epístolas a Lucilio, XCIX.

${ }^{7}$ Epístolas a Lucilio, LXIII.
} 
(basta recordar su postrera apelación a la solución jurídica en vez de a la venganza personal frente a la ofensa de los Infantes de Carrión) y que lo distingue efectivamente de muchos otros héroes emocionalmente desmesurados de las gestas medievales europeas.

El suspiro lenitivo, apaciguador del llanto, es la señal que se nos ofrece para indicar que el héroe doliente es capaz de vencerse a sí mismo. No es la única vez que la sucesión llanto/suspiro con ese mismo designio ocurre en el Poema. En la escena de la separación familiar antes de partir hacia el destierro - que es la otra ocasión en que se describe al héroe vertiendo lágrimassucede otro tanto. El episodio es dramático y culmina con el emotivo verso - hoy labrado en piedra en el Monasterio de San Pedro de Cardeña, donde ocurrió el suceso- que resume el dolor de la separación del Cid con su esposa y con sus hijas: «así s' parten unos d'otros commo la uña de la carne» (v. 375). Hay, en efecto, una escena en el curso de esta despedida en que se nos dice que el Cid «llora de los ojos, tan fuertemientre suspira» (v. 277); se trata de un momento en que el héroe tiene a sus dos hijas en brazos y está a punto de dirigirle a su esposa las últimas palabras. De nuevo el suspiro — que se emite «fuertemientre»- le ayuda a serenarse y conjurar el llanto para pronunciar acto seguido unas frases animosas y tranquilizadoras con el fin de aliviar la desesperación de la esposa, cuyo desconsuelo se manifestará, por el contrario, con un llanto sin control, desconcertado, muy distinto al suyo: «llorando de los ojos, que non sabe qué se far» (v. 370).

La función de los suspiros cidianos señala, por tanto, una expresión fisiológica tal vez inconsciente en su manifestación propia, pero enormemente reveladora de una voluntaria y general actitud psicológica del héroe: su decidida disposición a pasar del dolor personal paralizador al más noble y activo ejercicio de su responsabilidad social. Así, el mencionado suspiro del Cid que casi abría el poema (y la literatura española) es el que posibilita y prefigura no sólo el tono de mesura con que pronuncia sus primeras palabras en el Poe$m a$, sino el rosario de acciones y reacciones tan reveladoras que se describirán acto seguido:

Allí piensan de aguijar, allí sueltan las riendas.
A la exida de Bivar ovieron la corneja diestra
e entrando a Burgos oviéronla siniestra.
Meció mio Cid los ombros e engrameó la tiesta:
—-ilbricia, Álbar Fáñez, ca echados somos de tierra!-

Espolear el caballo («aguijar») y soltar las riendas no son acciones intrascendentes en ese instante, sino altamente significativas: significan que ha de terminarse la morosidad penosa de la salida, con esa mirada hacia atrás del héroe que volvía la cabeza melancólicamente para contemplar con pena lo que dejaba, y transformarse súbitamente en pura acción hacia delante, hacia el futuro, hacia la superación de las dificultades. En el mismo sentido hay que 
entender lo que se dice en los versos siguientes: el alternativo vuelo de las cornejas al salir de Bivar y al entrar en Burgos dibuja augurios buenos y malos en el mapa del cielo, pero el héroe reacciona quitando importancia a tales señales supersticiosas con un gesto gráfico y reconocible: encoger los hombros y sacudir la cabeza («Meció mio Cid los ombros e engrameó la tiesta»), porque sabe que él es el dueño de su destino y que este no está escrito aleatoriamente en las estrellas. Acto seguido se permite incluso una broma con su sobrino Álvar Fáñez, manifestando verbalmente un júbilo irónico por su destierro.

En apenas 14 versos, el héroe se ha vencido a sí mismo pasando desde las lágrimas iniciales hasta esta decidida desdramatización del problema (el primer requisito para resolverlo). Nada más adecuado que estos versos para hacer buenas las palabras de Colin Smith cuando se refería a ese realismo tan atractivo del Poema, «que se basa en el uso detallado y extenso de la potencialidad simbólica del cuerpo humano en cuanto a ademanes y posturas» (1977: 222). El suspiro inicial del $\mathrm{Cid}$ - y los gestos y expresiones que lo rodeanresultan, como hemos visto, del todo emblemáticos en este sentido.

\section{LOS «SOSPIROS CALLIENTES»DE NEMOROSO}

La presencia más común del suspiro literario se produce, puede imaginarse, en el ámbito del amor, como expresión de recuerdo, deseo o distancia respecto a lo amado. La gran poesía amorosa latina (Propercio, Tibulo, Catulo...) ya consignó, como no podía ser menos, esa manifestación del sentimiento entre los amantes, aunque será a lo largo de la baja Edad Media cuando el suspiro comparezca con inusitada frecuencia al calor de la poesía cortés y provenzal, pero también del nuevo espíritu religioso-devocional de la época. El medievalista benedictino Jean Leclercq hacía referencia a «toda una literatura de suspiria» en el monaquismo medieval, donde los suspiros «no son signo de tristeza, sino de aspiración» a la unión con lo divino y a los goces espirituales (2009: 85). Dante en su gran poema recogía, ya de modo literario y en un sentido dramático muy específico, ese suspiro espiritual al señalarlo como el rasgo característico de los habitantes del Limbo —espacio habitado por las almas que no tienen acceso a un Paraíso que anhelan, pues no llegaron a conocer el mensaje de Cristo-, donde «no había llantos, sino suspiros que hacían temblar el aura eterna» («Infierno», IV, vv. 26-27). El pagano Virgilio, que lo habita, insistirá más tarde en esos suspiros cuando lo describa como un lugar «no entristecido por los martirios, sino tan solo por las tinieblas, donde no suenan lamentos como ayes, sino suspiros» («ove i lamenti / non sonan come guai, ma son sospiri», «Purgatorio», VII, vv. 29-30).

Pero es evidente que los suspiros más esperables y más literarios se producían en la órbita de los deseos y aspiraciones humanas de tejas abajo. A 
partir del siglo XII, en el contexto cortesano y trovadoresco, la poesía amorosa europea se llenó de estas expresiones, que, en función del estado psicológico del suspirador, podían tomarse como señales benditas del amor o como signos malditos del tormento amoroso. Tales expresiones, en cualquier caso, se hicieron especialmente refinadas y espirituales en la doctrina del dolce stil novo, cuyo poeta más emblemático, Guido Cavalcanti, ya había establecido de modo axiomático en su célebre canción «Donna me prega» que el Amor «move sospiri» (v. 50). Dante poco después dotó de un marco escénico inmejorable a esta afirmación en el soneto que comienza «Tanto gentile e tan honesta pare» —incluido y parafraseado en su Vita nuova (XXVI) - , en el que la descripción altamente idealizada de la amada Beatriz culmina con la declaración de que el conjunto de sus bellezas va diciendo «suspira» al alma de todos los que la miran. Aunque a veces sea el delicado suspiro de la propia dama - que revela con ello su condición espiritual y su angélica melancolía - lo que arrebata al contemplador, como en aquel soneto de Petrarca (CLIX) en el que la exaltación platónica de la amada culmina en la afirmación de que todo lo ignora sobre el Amor aquel que no sabe cuán dulcemente ella suspira («chi non sa come dolce ella sospira»).

El suspiro significaba, por tanto, no sólo un signo del estado emocional de los amantes, sino también una manera espiritual de comunicarse entre ellos, y no era infrecuente encontrar en los textos a enamorados que afirmaban enviar a sus amadas el alma en un suspiro, al modo de un «beso descorporalizado» ${ }^{8}$, o que les pedían que les devolvieran, envuelta en un suspiro, el alma que les habían robado. Estas declaraciones no eran — como hoy puede parecernossimples metáforas, sino que se sustentaban en una suerte de física del amor de la que daban cuenta oportunamente los tratados tardomedievales. Así, en su Tractatus de amore heroico el médico aragonés Arnaldo de Vilanova (12381311) analizaba la «suspiriorum emissio» como síntoma del melancólico enfermo de amor, aunque también se consideraba eventualmente como una vía de escape para descansar el corazón repleto de sangre y «spiritus». Porque el suspiro se relacionaba, en efecto, con este spiritus — pneuma en griego- que era entendido desde Galeno como «materia sutil» que llegaba a los pulmones junto con el aire y que se extendía por las arterias a la vez que la sangre tras pasar por el corazón. Como veremos, los tratadistas neoplatónicos posteriores no se olvidaron en sus teorizaciones sobre el amor de este spiritus, que se desplazaba, según afirmaba Marsilio Ficino en su Theologia platonica (XVIII,

${ }^{8}$ Así lo dice Felipe Valencia en «"Acoged blandamente mi suspiro". El beso de almas en la poesía petrarquista española del siglo XVII» (2008: 279). El verso del título pertenece al soneto XXVII de Fernando de Herrera, donde la dulce mirada de la dama provoca que el amante le envíe un suspiro, al modo de un beso, para que llegue hasta el alma de ella. Serés se refería a ese verso herreriano afirmando que el suspiro era, como en casos similares, un beso «aludido por contigüidad metonímica» (1996: 254). 
4) «in vehiculo aethereo et aereo», pero del que se hablaba como de una realidad cierta, aunque sutil.

Con la ayuda de tales presupuestos podemos ya abordar con ciertas garantías los suspiros de Nemoroso en la Egloga I de Garcilaso (vv. 352-365), emitidos en el contexto de su duro duelo por la prematura muerte de su amada Elisa:

1 Tengo una parte aquí de tus cabellos, Elisa, envueltos en un blanco paño, que nunca de mi seno se m'apartan; descójolos, y de un dolor tamaño

5 enternecer me siento que sobre'llos nunca mis ojos de llorar se hartan.

Sin que d'allí se partan, con sospiros callientes, más que la llama ardientes,

10 los enjugo del llanto, y de consuno casi, los paso y cuento uno a uno; juntándolos, con un cordón los ato.

Tras esto el importuno dolor me deja descansar un rato.

Como ha señalado la crítica, Garcilaso recrea en esta estrofa el fervor fetichista por las prendas de la mujer amada (cabellos, cintas, vestidos...) que era habitual en la tradición bucólica, pero que también comparecía en otros géneros literarios (recuérdese la devoción de Calisto por el «cordón» de Melibea que le lleva Celestina). Pero Garcilaso toma aquí como pauta unos versos de Sannazaro en su Arcadia (XII, 313-318), donde el pastor Meliseo guarda en un cestillo cabellos de su amada Filis, que ha muerto, y a veces los saca para llorar sobre ellos y con un suspiro los seca y luego los recoge («et lascio sopra lor questi occhi piovere, / poi con sospir li ascuigo e insieme accolgoli»). Garcilaso hace que Nemoroso repita la mecánica fetichista de Meliseo, pero añade dos detalles fundamentales, que elevan el patetismo de la acción: el llevar siempre consigo, junto a su pecho, el hato de los cabellos, cerca del corazón, así como el hecho de contarlos fervorosamente «uno a uno» cuando lo desata. Y, por otro lado, el calificar los suspiros de «callientes», que es lo que aquí nos interesa. Lo primero que habría que decir es que este «callientes» no es un epíteto, sino un adjetivo especificativo que expresamente nos quiere decir cosas muy concretas sobre esos «suspiros» y que apunta, como ahora veremos, en varias direcciones: fisiológicas y culturales, literales y metafóricas.

Una lectura apresurada y superficial estaría tal vez tentada de entender el adjetivo en un sentido eminentemente metafórico: las llamas del amor hacen que los suspiros del enamorado sean calientes, de modo parecido a como el fuego de la ira hace que algunos iracundos que están sumergidos en el Infierno de Dante hagan hervir con sus suspiros el agua que los cubre: «che sotto l'acqua ha gente che sospira / e fanno pullular quest'acqua al summo» (vv. 
118-119). Pero la emisión y el calor de estos suspiros, de acuerdo con los mencionados tratadistas de la época, es algo más que una simple metáfora. Tomando como pauta el capítulo IV, 6 del De amore de Ficino, podríamos muy bien argumentar que, a la vista del mechón de cabellos de su amada Elisa, Nemoroso provoca la ebullición de esos «vapores sutilísimos generados del calor de la sangre del corazón» que constituyen el spiritus, concebido por Ficino como «vehículo e instrumento del alma» y encargado, entre otras cosas, de acudir a los depósitos de la memoria para representar la imagen de la persona amada en virtud de la facultad de la imaginación. Porque, como explica Pietro Bembo a través de Castiglione en el último capítulo de El Cortesano, en ausencia de la persona amada, la pasión amorosa del enamorado puede inflamar el corazón, el cual calienta los espíritus que vienen de los pulmones, pero, al no encontrar estos espíritus cauce al exterior por los ojos o por la boca, pues no existe la persona amada a la que enviárselos, «hállanse sin salida y porfían cuanto más pueden por salir, (...) y de aquí proceden las lágrimas, los sospiros...».

Los «sospiros», en efecto, y «callientes» por añadidura. Pero esos «sospiros callientes» están vinculados, por otra parte, muy estrecha y consecuentemente a la cadena del relato que se nos cuenta. Y permítasenos hacer a este propósito un breve inciso para subrayar la extraordinaria - y muy garcilasiana- cualidad narrativa de la estancia que comentamos, en la que la alta poesía de Garcilaso se fundamenta exclusivamente en su excelente condición rítmica y en su delicado lirismo, y no en ninguna imagen poética o en ninguna especial figura retórica (lo único que existe en este sentido es el tópico símil y el leve hipérbaton del v. 9: «más que la llama ardientes»). Pues bien, la alta temperatura de esos «sospiros» de Nemoroso también nos viene justificada por el llanto que rodea la emisión suspirante, tal como se subraya de manera expresa en los versos anteriores y posteriores a la mención de la misma. ¿ $\mathrm{Y}$ acaso no sabemos todos por experiencia que el llanto calienta el aliento y, por tanto, el suspiro? Y, por otro lado: la temperatura de esos suspiros que salen «callientes» es la que justifica con la máxima verosimilitud la acción que se cuenta en el verso siguiente: «los enjugo del llanto». Nemoroso seca, en efecto, con sus cálidos suspiros los cabellos de la amada Elisa que sus lágrimas previamente han mojado (de otro modo le sería difícil llegar a separarlos y contarlos del modo que lo hace: «uno a uno»).

La excelencia de la poesía se encuentra a menudo en los pequeños detalles. El adjetivo «callientes», aparentemente tópico y poco relevante, con que califica el vate toledano a los suspiros de Nemoroso en una «escena» ya previamente creada por Sannazaro, se convierte aquí, sin embargo, en elemento crucial y en extremo relevante para potenciar la escena en varias direcciones y dotar del máximo sentido a lo que se nos cuenta. Un pequeño pero revelador detalle, para demostrar, por si hiciera falta, lo enorme y fino poeta que era Garcilaso. 


\section{El angustiado SUSPIRO DE VALDOVINOS}

Nuestro tercer suspiro lo encontraremos en uno de los poemas que en el Romancero tienen por protagonista a Valdovinos. El romance está documentado ya por escrito en el siglo XV y pertenecería, en palabras de Menéndez Pidal, a esa «segunda generación de romances populares, derivados de los juglarescos», que ya no trata temas de épica nacional, sino asuntos y figuras ajenos a la tradición peninsular, fundamentalmente inspirados en la prolífica epopeya francesa (1973: 22) ${ }^{9}$. Este romance deriva en concreto de la Chanson des Saisnes (de los Sajones) de hacia 1200, que narra la campaña de Carlomagno contra los sajones del Rhin y tiene como protagonista a su sobrino, el caballero Baudouin (que en castellano será Valdovinos), y a una ardiente reina sajona llamada Sebile.

Se trata, pues, de un romance del ciclo épico carolingio, sobre cuya materia original se llevaron a cabo, sin embargo, curiosísimas trasposiciones: el mismo nombre de la reina, Sebile, transporta la acción hasta las proximidades de Sevilla; el Rhin, que era el escenario de los amores de Baudouin, se ha transmutado en «los caños de Carmona» (de gran presencia, por cierto, en la literatura popular); y el amor del protagonista ya no recae sobre una sajona, sino sobre una musulmana, con lo que el romance «carolingio» se fusiona con el espacio y los motivos de los romances «fronterizos» $\mathrm{y}$ «moriscos» en una singular e inesperada hibridación. Bien se cumple en este caso aquella observación de carácter general que formulaba el propio Pidal sobre las vinculaciones con la épica francesa de estos romances de segunda generación, que «se elaboraban por los juglares y el pueblo castellano de una manera por demás genial y desenfadada», implementando, por otro lado, sobre el tradicional «espíritu austero de los romances de asunto castellano, algo más de pasión y sentimentalismo» (1973: 23). También se comprueba esto último en el romance que nos ocupa, aunque se produzca asimismo, tal como veremos, una profunda españolización de la materia francesa (y no sólo en lo referente a su modalización morisca y fronteriza).

Pero pasemos sin más preámbulos a transcribir este Romance de Valdovinos, que tiene, como es presumible, algunas variantes de detalle y nos ha llegado incluso en una versión completa algo distinta — la que comienza «Tan claro nace la luna»-, pero que en lo esencial es parecida a la que aquí mostramos (también, y sobre todo, en lo referente al «suspiro» del protagonista). La versión que ofrecemos, en cualquier caso, es la mejor y la más atendida ${ }^{10}$ :

\footnotetext{
${ }^{9}$ Las relaciones de la epopeya francesa con el romancero español fueron investigadas y establecidas en diversos trabajos por el propio Pidal y continuadas por su nieto y discípulo Diego Catalán. Pidal trató en concreto la relación de la figura de Valdovinos en el romancero español con su procedencia francesa, en «La Chanson des Saisnes en España» (1951: 229-44).

${ }^{10}$ Nos atenemos a la edición de J. Rodríguez Puértolas (1992: 127-128).
} 
1 Por los caños de Carmona, por do va el agua a Sevilla, por ahí iba Valdovinos y con él su linda amiga.

5 Los pies lleva por el agua y la mano en la loriga, con el temor de los moros no le tuviesen espía. Júntanse boca con boca,

10 nadie no los impedía. Valdovinos, con angustia, un suspiro dado había:

- ¿Por qué suspiráis, señor, corazón y vida mía?

$15 \mathrm{O}$ tenéis miedo a los moros, o en Francia tenéis amiga.

- No tengo miedo a los moros ni en Francia tengo amiga, mas vos mora y yo cristiano

20 hacemos muy mala vida, comemos la carne en viernes, lo que mi ley defendía ${ }^{11}$, siete años había, siete, que yo misa no la oía;

25 si el emperador lo sabe la vida me costaría.

-Por tus amores, Valdovinos, cristiana me tornaría.

-Yo, señora, por los vuestros,

30 moro de la morería.

El romance puede dividirse en tres partes fácilmente distinguibles: una primera contextual, preparatoria, hasta el verso 8 , en la que encontramos la presentación del espacio, la situación y los personajes; una segunda, de los versos 9 a 12, en la que se describe el momento culminante del relato: el beso de los amantes y el suspiro subsiguiente de Valdovinos; y una tercera y última parte donde tiene lugar el diálogo posterior, que da cuenta del estado psicológico y emocional de los protagonistas.

El poema se abre en la primera parte con la mención a los «caños de Carmona», es decir, los restos del acueducto romano que a la sazón llevaba el agua hasta la llamada «puerta de Carmona», en la antigua muralla de Sevilla. En pocos versos introductorios el romance sugiere con gran eficacia la alerta y

\footnotetext{
${ }^{11}$ En la época «defender» tenía también el significado de «prohibir» (significado que hoy prevalece, por cierto, en lengua francesa). En cuanto al extraño uso verbal del pretérito imperfecto - defendía en vez de defiende-, es, como se sabe, una singularidad morfológica en la lengua poética del Romancero (que se repite en los verbos de los dos versos siguientes: «había» y «oía»).
} 
el peligro que se ciernen sobre Valdovinos y «su linda amiga» ${ }^{12}$. En efecto, Valdovinos, para no dejar huella a su paso «los pies lleva por el agua», y lleva «la mano en la loriga», dispuesto a desenvainar la espada o el puñal con rapidez para defenderse de un posible ataque de «los moros» que tal vez le espían. Pero el romance, sin transición, abandona en el verso 8 esa sensación grávida de amenaza externa para relatarnos inesperadamente en el verso siguiente el beso «boca con boca» de los amantes: su entrega súbita y recíproca al contacto físico a despecho de todos los temores y de todos los peligros. ¿Puede sugerirse con mayor énfasis la pasión irresistible que los anima? Pero, a renglón seguido, llega el momento clave del poema: el suspiro angustiado de Valdovinos. Este suspiro - hay que recordarlo- estaba ya en el relato épico francés y a no dudarlo es el elemento que hizo surgir el romance castellano. Sin embargo, el suspiro de Baudouin ante la reina sajona era sensiblemente distinto, porque tenía que ver con un imaginado desamor o desafección hacia él por parte de Sebile, no, como en el romance español, con el conflicto entre el amor y sus deberes de cristiano. Hay, pues, en este motivo clave del suspiro una decisiva españolización del asunto, que convierte el suspiro sentimental en un dilema de carácter ético y religioso.

La expresión de este grave dilema - y las consecuencias que de él pueden derivarse- es lo que se desarrolla en las cuatro intervenciones que constituyen el diálogo que conforma la tercera y decisiva parte del poema. Alarmada por el suspiro que sucede al apasionado beso, la mujer pregunta por su causa, considerando que han de ser razones de corte emocional, basadas en el miedo a los peligros que Valdovinos arrostra por estar con ella o en el amor oculto de su amado por otra mujer. La mujer no es capaz de imaginar otras razones que justifiquen el suspiro «con angustia» de Valdovinos. Pero Valdovinos la saca de su limitado universo sentimental para descubrirle las razones éticas y religiosas que avalan y explican su angustiado suspiro, debido, en último término, a la «mala vida» que ambos llevan: el carácter irregular - heterodoxo y extramatrimonial- de sus relaciones y el largo incumplimiento de sus deberes como católico cristiano. Pero Valdovinos termina su argumentación manifestando una fisura en la naturaleza moral de sus angustias, pues alude en los versos 25-26 a un posible castigo del emperador Carlomagno, lo que termina abocando su razonamiento al terreno del miedo, que está en la órbita femenina y emocional del argumentario de la mora. Esta fisura, esta debilidad, propicia asimismo la inmediata réplica de la mujer, que es una súbita y extralimitada declaración amorosa (extralimitación que se refleja incluso métricamente en el v. 27, que mide 9 sílabas en vez de las 8 pertinentes), cuya misión es abortar definitivamente el razonamiento moral de Valdovinos y llevar la cuestión de nuevo al terreno sentimental.

${ }^{12} \mathrm{El}$ adjetivo «linda» es, por cierto, el único de todo el poema — si exceptuamos el lexicalizado de «la mala vida» del v. 20- y remite a un rasgo de acaso frívola hermosura exterior muy a tono con el origen francés y galante de la historia. 
La mora es lista (o intuitiva, que viene a ser lo mismo) y sabe que una declaración de amor tan explícita, tan contundente, reclama, casi exige, otra similar por parte del destinatario si este no quiere quedar desairado a los ojos de ella, a los ojos del Amor (que ella aquí asume que representa). Valdovinos, en efecto, cae en la trampa y termina pronunciando la declaración recíproca y correspondiente, que en su boca suena a claudicación casi blasfema (de hecho, estos dos últimos versos fueron censurados en algunas ediciones). Algo de esta claudicación ya podía anticiparse en la comentada torsión emocional -y extramoral - de los últimos versos de su primera intervención, pero su declaración final tiene todo el aspecto de una concesión, que no parece que vaya a acabar con sus angustias. Intuimos que a la «linda» mora no le costaría demasiado renunciar a su religión y hacerse cristiana en aras del amor. Pero sospechamos que a Valdovinos sí que le costaría hacer lo contrario. Ahí está su drama. Y su derrota.

Una vez más resulta admirable ver cómo los anónimos creadores del Romancero logran en los mejores casos provocar tantas sugerencias y abordar tantos matices en los pocos y sencillos versos de sus creaciones. En el caso que nos ocupa, la sensación de amenaza, la irrupción del deseo, el desvelamiento de la psicología abismática de los amantes (y de los sexos), sobre la base de una materia ajena finamente modelada, son realmente extraordinarios. Y todo ello llevando hasta el extremo la virtualidad dramática y narrativa de un suspiro. Era la primera vez que esto ocurría con todas las implicaciones que hemos señalado, pero no iba a ser la única en la literatura española, como veremos a continuación.

\section{LOS SUSPIROS DEL ABENCERRAJE}

Para examinar los próximos suspiros no saldremos de ese mismo espacio «de frontera» que trataba el romance de Valdovinos, aunque ese espacio se considere ahora como un elemento tan relevante que se convierta en caracterizador de todo un género narrativo, específicamente español por añadidura. Nos referimos, claro está, a la novela morisca, y en concreto a la obra que inauguró el género a mediados del siglo XVI: la historia de El Abencerraje y la hermosa Jarifa.

Menos leído y conocido que el Lazarillo y menos innovador como propuesta estética, el Abencerraje es, sin embargo, una verdadera obra maestra que no desmerece del inaugural relato picaresco y que, como este, no tiene parangón en la literatura europea de la época. A despecho de sus distintos registros en cuanto al estilo literario y de sus antagónicas visiones del mundo y de la vida — una idealista y refinada, otra pragmática y realista, aunque ambas representativas por igual del espíritu del Renacimiento-, el Abencerraje y el Lazarillo quedan hermanados curiosamente por ciertos rasgos significativos: ambas 
son obras breves y anónimas, estrictamente coetáneas entre sí, e inauguraron los dos géneros autóctonos de la narrativa española del Siglo de Oro: la novela morisca y la novela picaresca

El Abencerraje es un delicado cuento de frontera que exalta el amor, la galantería, la nobleza de espíritu y el valor de la amistad entre las almas bellas, por encima de excluyentes adscripciones raciales o religiosas, sin por ello dejar de apuntar, como veremos, finos detalles de ironía y observación psicológica a ras de suelo. Recordemos brevemente su argumento (aunque sólo una atenta lectura y un amplio comentario podrían dar cuenta cabal de sus altas virtudes literarias). En una batida con sus hombres por la frontera granadina, el caballero cristiano Rodrigo de Narváez, alcaide de Álora y Antequera, logra capturar al valeroso moro Abindarráez (del noble pero desdichado linaje de los Abencerrajes), que iba al encuentro de una cita amorosa con su prometida Jarifa, a la que no veía desde hacía tiempo, para casarse en secreto con ella. Al descubrir esta circunstancia y reconocer el noble corazón de su prisionero, don Rodrigo le deja marchar generosamente para que se case con su enamorada bajo palabra de volver en el plazo de tres días. Abindarráez acude a su cita y vuelve, efectivamente, con la propia Jarifa en el término acordado. Conmovido por la pasión de los amantes y la belleza de la mora, Rodrigo de Narváez no sólo les concede la libertad definitiva sino que intercede delante del padre de la muchacha para que acepte ese matrimonio.

Los suspiros de Abindarráez son decisivos a lo largo del relato. Los primeros se producen en el momento de su captura. Después de una larga contienda en la que el Abencerraje va derrotando con habilidad y coraje a varios caballeros cristianos, cede finalmente ante el empuje de Rodrigo de Narváez. Reducido al fin, y magullado, Abindarráez es subido a un caballo para ser llevado preso al campamento cristiano. Mientras Narváez y sus hombres iban comentando

la buena disposición y valentía del moro, él dio un grande y profundo sospiro, y habló algunas palabras en algarabía, que ninguno entendió. Rodrigo de Narváez iba mirando su buen talle y disposición; acordábasele de lo que le vio hacer, y parecíale que tan gran tristeza en ánimo tan fuerte no podía proceder de sola la causa que allí parescía ${ }^{13}$.

La aplicación a «suspiro» del adjetivo «profundo» era muy corriente en la lengua literaria, hasta el punto de que el Tesoro de la lengua castellana (1611) de Sebastián de Covarrubias incluye ese adjetivo en la propia definición de la palabra: «SOSPIRAR: sacar el espíritu de lo profundo del pecho, con sinificación del dolor y ansia que padecemos». Sea como fuere, ante el «profundo sospiro» de Abindarráez, don Rodrigo queda sorprendido, pues esa explícita muestra de dolor ante la derrota no se compadece, a su juicio, con el estoicis-

${ }^{13}$ Utilizamos la edición de Francisco López Estrada (1980). 
mo que debe adornar la conducta de un caballero tan noble y valeroso como ha demostrado ser el jinete moro. Por eso deduce inmediatamente que el motivo de su angustia debe ser otro. Y no yerra.

El suspiro no es un signo unívoco, cerrado, y como tal resulta por demás atinente a ese lábil lugar de fronteras en el que se desarrolla la acción. Un espacio que remite ciertamente a un choque de culturas, cuyo conflicto se refleja en primera instancia en la barrera de las lenguas (los cristianos no entienden la «algarabía» — es decir, la lengua árabe — en la que el moro musita su pena), pero que también resulta o puede resultar un espacio tangencial de fusión y superación de conflictos, o de derivación de los mismos hacia terrenos comunes de entendimiento. El suspiro es en este sentido un «protolenguaje» universal cuya polivalencia, también fronteriza, posibilita pasar del ámbito épico-guerrero (en el que los hombres se enfrentan) al ámbito amoroso-sentimental (en el que se reconocen las almas bellas de cualquier condición). Esta naturaleza del suspiro del Abencerraje ha sido bien entendida y analizada por Luis F. Avilés: «Este suspiro es un evento fundamental para entender la nueva desarticulación de los parámetros determinantes del espacio fronterizo después de la escaramuza y la captura del moro. ¿Por qué es tan importante el suspiro? Simplemente porque ese gesto comienza a disolver la barrera fundamental que separa a los enemigos, la cual está constituida por diferencias culturales y lingüísticas» (2003: 460). En efecto, este suspiro del Abencerraje - como sucede, ya lo sabemos, en otros casos - tiene un carácter performativo que provoca acciones y disposiciones de modo inmediato, hasta el punto de constituir el elemento desencadenante de toda la acción subsiguiente del relato, generando un diálogo que abole la distancia del espacio público fronterizo entre vencedor y vencido y propiciando otro espacio privado proclive al encuentro y la confraternización.

Rodrigo de Narváez, en efecto, ha leído bien el misterio que esconde el suspiro de su hasta entonces enemigo (en el orden guerrero y religioso), y acaba llevándoselo a un lugar apartado para que el moro pueda abrirle su alma y relatarle la aflicción por la que suspira, un relato que comienza, por lo demás, «arrancando un gran suspiro» y en donde Abindaráez le da cuenta de su historia: la desdicha de su linaje, injustamente marginado por el rey moro de Granada, su temprano y delicado amor por la noble Jarifa, su obligada separación de la muchacha y la promesa por parte de esta de llamarlo a su lado cuando fuera posible para consumar su amor en matrimonio secreto ${ }^{14}$, una cita cuyo anuncio ya se había producido y a la que precisamente acudía cuando fue capturado. Al escuchar tan sentida historia, don Rodrigo, como ya sabemos, le permite acudir a la cita amorosa siempre que vuelva al cabo de tres días. Con tal compromiso y lleno de gratitud, Abindarráez acude veloz a su

${ }^{14}$ En la fecha de publicación del Abencerraje, y hasta su prohibición por el Concilio de Trento en 1564, estos matrimonios secretos bajo palabra eran lícitos en el propio contexto cultural cristiano. 
encuentro clandestino de esa misma noche con Jarifa, a la que encuentra esperándole secretamente en uno de los aposentos de su castillo. Poseídos por el amor y por el deseo, los enamorados los ponen por obra nada más verse en una noche de pasión (quizá para no estropearla, el Abencerraje no ha comunicado las precarias condiciones de ese encuentro). Sigue aquí el texto del relato:

Tras esto, al moro vino un profundo pensamiento, y dejando llevarse de él, dio un gran sospiro. La dama, no pudiendo sufrir tan grande ofensa de su hermosura y voluntad, con gran fuerza de amor le volvió a sí y le dijo:

- ¿Qué es esto, Abindarráez? Paresce que te has entristecido con mi alegría; yo te oyo sospirar revolviendo el cuerpo a todas partes. Pues si yo soy todo tu bien y contentamiento como me decías, ¿por quién sospiras?; y si no lo soy, ¿por qué me engañaste? Si has hallado alguna falta en mi persona, pon los ojos en mi voluntad, que basta para encubrir muchas; y si sirves otra dama, dime quién es para que la sirva yo; y si tienes otro dolor secreto de que yo soy ofendida, dímelo, que o yo moriré o te libraré de él.

Aunque la coyuntura del «gran sospiro» del Abencerraje, después de haber yacido con Jarifa, coincida con la conocida «tristitia post coitum», el lector sabe que en este caso no es un síntoma de ella. Pero Jarifa, que no lo sabe, nunca podría achacarlo a aquella tristeza — que es de índole más bien universal y metafísica-, porque no concibe ningún suspiro de su amante que no esté directamente relacionado con su propia persona. En realidad, no se equivoca en este punto, pero sí en todo lo demás. A diferencia de don Rodrigo, Jarifa lee mal este suspiro del Abencerraje. A tenor de sus palabras, podemos intuir muy claramente las causas que ella imagina: 1) que hay otra mujer (lo mismo que pensaba, por cierto, la «linda mora» de Valdovinos); 2) que, al descubrir ella su cuerpo en la entrega amorosa, él no ha quedado complacido por algún aspecto de su físico (o acaso —imaginémoslo- por sus pocas mañas sexuales); y 3) que alguien tal vez le ha hablado mal de ella (en contra de su fama o de su honor). El Abencerraje de inmediato la saca de su error y, emitiendo de nuevo «un apasionado sospiro», le asegura que «mis sospiros se causan más de sobra de lealtad que de falta de ella»; acto seguido le comunica todo lo que el lector ya sabe: su captura y su necesaria vuelta a la prisión al cabo de tres días (circunstancia que, al suponer la separación de los amantes, es la que en realidad ha originado su suspirar).

Los suspiros de Abindarráez actúan siempre, efectivamente, en un espacio fronterizo, pero no sólo en la frontera cultural y guerrera entre moros y cristianos, sino también en la universal frontera entre hombres y mujeres, y no sólo para saltar esas barreras, sino también para evidenciarlas. El suspiro ante Jarifa resulta obviamente el síntoma de las emociones del Abencerraje, pero asimismo es el desencadenante que manifiesta un claro desajuste entre los amantes en lo que toca a valores y visión del mundo, como se manifestará inmediatamente después. Cuando Abindarráez le comunica que debe volver a 
manos de su captor cristiano para cumplir su promesa, Jarifa le dice que no haga tal cosa y que, en vez de eso, le envíe un rescate en forma de dinero. El enamoramiento de Abindarráez por su dama suaviza su reacción de absoluto rechazo ante esa propuesta, que él califica como «un gran yerro», y la interpreta, aunque no justifica, con estas palabras: «Bien parece, señora mía, que lo mucho que me queréis no os deja que me aconsejéis bien».

El talante pragmático pero moralmente poco ejemplar de Jarifa, que, como la mora de Valdovinos, no se rige por criterios éticos sino pasionales, queda subrayado por una nueva anécdota en el curso del relato. En el camino que la pareja emprende al cabo de tres días para cumplir la promesa, encuentran a un anciano que les comenta que él va también a Álora para entrevistarse con su alcaide, Rodrigo de Narváez, «el más honrado y virtuoso caballero que yo jamás vi». Para demostrarlo les cuenta la siguiente anécdota: don Rodrigo estaba rendidamente enamorado de una dama casada que se mostraba indiferente a sus persistentes requiebros. Un día esa dama escucha ponderar a su propio marido la sobresaliente virtud y coraje de don Rodrigo, por todos conocida, y esa alabanza le provoca el deseo de acceder a los ruegos de su galanteador, al que convoca una noche a una cita secreta. Ya en el aposento donde los citados van a consumar sus deseos, la dama le refiere a don Rodrigo el comentario de su marido que le ha suscitado el afán de conocerlo. Don Rodrigo, al enterarse, renuncia en el acto a su apasionado deseo de poseer a la dama o de hacer cualquier cosa que deshonre a un hombre que habla tan bien de él, y se marcha del aposento. El comentario de Jarifa a este suceso no tiene desperdicio, al argüir que don Rodrigo «debía estar poco enamorado, pues tan presto se salió afuera y pudo más con él la honra del marido que la hermosura de la mujer».

¿Qué sentido tiene introducir esta anécdota en el curso del relato sino la voluntad expresa del anónimo autor por manifestar de nuevo que Jarifa es impermeable a las exigencias universales de la ética y se mueve solo por intereses sentimentales de carácter personal? Sus sesgadas interpretaciones del suspiro de Abindarráez ya permitían sospecharlo, del mismo modo que la prudente lectura que de su anterior suspiro había efectuado Rodrigo de Narváez presagiaba entre ambos estrechas afinidades espirituales. Y es que el suspiro es un signo inequívoco de alguna emoción, pero no deja por ello de ser abierto y revelador en sus significados últimos. Creo que sería difícil encontrar otro relato que explorase mejor y más sutilmente —y con más potenciales implicaciones - esa zona de obligada apertura significacional que tienen los suspiros que la presente Historia del Abencerraje y la hermosa Jarifa.

\section{El PARÓDICO SUSPIRAR DE DON QUIJOTE}

Los primeros suspiros de don Quijote a los que asiste el lector tienen lugar en su primera salida, tras ser vapuleado por el mozo de mulas de unos 
mercaderes a los que extemporáneamente quería el hidalgo imponer una declaración tajante sobre la inmarcesible belleza de Dulcinea. Dada la fina sensibilidad literaria de Miguel de Cervantes no nos puede sorprender demasiado que esos suspiros tan teatrales de su personaje — «unos suspiros, que los ponía en el cielo»— vengan acompañados de un recuerdo literario muy significativo en la mente del postrado y vencido hidalgo: el «del moro Abindarráez, cuando el alcaide de Antequera, Rodrigo de Narváez, le prendió y llevó cautivo a su alcaldía» $(\mathrm{I}, 5,78-79)^{15}$. Cervantes, pues, nos presenta desde el inicio a su suspirante protagonista —uno de los más suspirantes de la literatura española- enlazado a la tradición literaria de otro conocido suspirante de amor por verse impedido de acceder a su dama. Porque esta va a ser, en definitiva, la tesitura última de todos los suspiros quijotescos, cuyo referente será siempre la ausente Dulcinea.

Hagamos un breve repaso de ello en la Primera Parte de la obra. De don Quijote escapa «un gran suspiro» cuando refiere las gracias y bellezas de Dulcinea al caminante Vivaldo (I, 13, 154), suspira al referirse a ella hablando con Sancho (I, 21, 248), «envuelto entre sus suspiros» (I, 26, 321) lo presenta Cervantes cuando hace su «penitencia de amor» en Sierra Morena, donde su escudero lo encuentra «desnudo en camisa, flaco, amarillo y muerto de hambre, y suspirando por su señora Dulcinea» (I, 29, 366); lo vemos luego, mientras vela sus armas por ella en la venta de Juan Palomeque, dar «de cuando en cuando tan dolientes y profundos suspiros, que parecía que con cada uno se le arrancaba el alma» (I, 43, 553); y lo contemplamos al final de la Primera Parte, «dando un gran suspiro» por su apartada Dulcinea mientras lo llevan «encantado» en una triste jaula hasta su aldea (I, 46, 589). En la Segunda Parte don Quijote suspira en las afueras del Toboso mientras espera que llegue Sancho con nuevas de Dulcinea (II, 10, 768), suspira al entrar en casa de don Diego de Miranda y ver en la bodega unas tinajas del Toboso que le recuerdan a su amada (II, 18, 841), suspira cuando la duquesa le pide que describa la belleza de Dulcinea (II, 32, 978) y suspira cuando, volviendo ya por última vez hasta su aldea, canta una triste canción lamentando su suerte, que «acompañaba con muchos suspiros y no pocas lágrimas, bien como aquel cuyo corazón tenía traspasado con el dolor del vencimiento y con la ausencia de Dulcinea» (II, 68, 1292). Por primera y única vez el llanto hace su aparición en el rostro de don Quijote, y se adereza aquí con los suspiros en una mezcla muy común, como sabemos, en la literatura amorosa y sentimental.

Pero ¿cómo ocultar que para los lectores del Quijote los suspiros del protagonista, además de al amor, obedecen a otras causas? ¿Cómo ignorar que el suspiro es un signo relevante en el lenguaje no verbal del espíritu de la melancolía, y cómo ignorar que ese espíritu campea a sus anchas en la universal

${ }^{15}$ Seguiremos en adelante la edición del Instituto Cervantes dirigida por F. Rico (Cervantes, 2004). 
novela cervantina? Hace ya casi 20 años me explayé a fondo sobre este asunto, considerando que el Quijote era un libro escrito por un melancólico sobre un personaje melancólico y dirigido a una España en crisis, atravesada por la melancolía (García Gibert, 1997: 65-161). Argumentaba en aquel ensayo cómo Cervantes dotaba al manierismo melancolizante del Renacimiento — donde se produjo una verdadera glorificación humanista del temperamento melancólico, entendido como condición distintiva del intelectual y del artista- de un sentido ya universal y totalmente reconocible en nuestros días, que a la vez iba más allá —aunque subsumiéndolo- de la modalización particular del desengaño barroco ${ }^{16}$. La melancolía de don Quijote nace del choque sistemático de los bellos ideales con la cruda realidad, de la imposibilidad de alcanzar la gloria y el reconocimiento que él cree merecidos, de la pasión por un tiempo ya ido, es decir, de una serie de pérdidas y frustraciones existenciales, de las cuales la desaparecida Dulcinea es sólo la punta del iceberg. Pero esta melancolía está a menudo coloreada por el humor y matizada siempre por el prisma de la insondable ironía de su autor.

A esta amalgama de tonos y registros, tan típicamente cervantina, va a responder el suspiro quijotesco que examinaremos a continuación, un suspiro ciertamente paródico, pero que se produce en un contexto de fuerte carga emocional, en el capítulo 44 del Quijote de 1615, que representa a mi juicio un punto de inflexión indiscutible en el proceso melancolizante que avanza implacable en la Segunda Parte de la obra. He aquí el prólogo contextual de ese suspiro: Sancho ha marchado a la ínsula Barataria y su amo se queda solo en el palacio de los Duques. Así lo expresa el narrador:

Cuéntase, pues, que apenas se hubo partido Sancho, cuando don Quijote sintió su soledad, y si le fuera posible revocarle la comisión y quitarle el gobierno, lo hiciera. Conoció la duquesa su melancolía y preguntole que de qué estaba triste, que si era por la ausencia de Sancho, que escuderos, dueñas y doncellas había en su casa que le servirían muy a satisfacción de su deseo.

- Verdad es, señora mía — respondió don Quijote-, que siento la ausencia de Sancho, pero no es ésa la causa principal que me hace parecer que estoy triste, y de los muchos ofrecimientos que Vuestra Excelencia me hace solamente acepto y escojo el de la voluntad con que se me hacen, y en lo demás suplico a Vuestra Excelencia que dentro de mi aposento consienta y permita que yo solo sea el que me sirva.

Esta conversación entre don Quijote y la duquesa a la hora de la cena prosigue explayándose en la ironía paródica que late en un fondo de melancolía auténtica, al expresar el hidalgo su temor a que las doncellas que le sirvan pudieran provocar en él algún mal deseo y tratar la duquesa de tranquilizarle

${ }^{16}$ En último término, el suspiro melancólico de la época podría entenderse como una variante contenida de ese efusionismo lacrimógeno del contrarreformismo barroco cuya funcionalidad ha examinado en un libro reciente A. González Roldán (2009). 
sobre esta cuestión. Don Quijote, acabada la cena, se retira de inmediato a sus aposentos, y dice entonces el narrador:

Cerró tras sí la puerta, y a la luz de dos velas de cera se desnudó, y al descalzarse, ¡oh desgracia indigna de tal persona!, se le soltaron, no suspiros ni otra cosa, que desacreditasen la limpieza de su policía, sino hasta dos docenas de puntos de una media, que quedó hecha celosía.

Cervantes juega, como tantas veces, con las expectativas del lector, porque la situación por él diseñada debería en ese momento abocar al suspiro en un personaje tan suspirante como sabemos que lo es don Quijote. Pero el narrador la menciona sólo para negarla y, al hacerlo, la posibilidad del suspiro y el propio concepto del suspirar quedan degradados por su contacto sintagmático con la alusión a las ventosidades, a las que obviamente se refiere con reticente eufemismo: «otra cosa» que desmintiese «la limpieza de su policía» (tomado aquí «policía» en su acepción, común en la época, de urbanidad y buena crianza).

Cervantes mezcla, como suele, burlas y veras, piedad e ironía en todo este fragmento. Al advertir la soltura de los puntos, reveladora de su miseria material, don Quijote «afligiose en estremo», pues vive tanta pobreza como una afrenta moral a su dignidad de hidalgo. Cervantes se demora entonces con su personaje en la intimidad de su aposento y se complace en hacernos asistir a la angustia secreta y privadísima de un ser humano que se recuesta «pensativo y pesaroso» sobre su cama y al que veremos ejecutar a continuación esos actos anónimos e insignificantes en los que reconocemos, por así decirlo, el ritual no escrito del desasosiego insomne:

Mató las velas; hacía calor y no podía dormir; levantose del lecho y abrió un poco la ventana de una reja que daba sobre un hermoso jardín...

Pero desde esa ventana abierta vendrá de nuevo el aluvión burlesco: el hidalgo escucha una conversación entre dos voces femeninas, una de las cuales, que dice llamarse Altisidora, se proclama rendidamente enamorada de don Quijote y, ni corta ni perezosa, entona unos disparatados versos de amor, con el acompañamiento de un arpa. Ni que decir tiene que esta supuesta doncella enamorada es una criada que pone por obra uno de las burlas que idean los duques para ver la reacción de su invitado, el cual obviamente, en su enajenación caballeresca, cree a pies juntillas la verdad del disparate.

Terminado el cantar de Altisidora es cuando Cervantes cree oportuno encajar el suspiro que antes había mencionado sólo para abortarlo.

Aquí dio fin el canto de la malferida Altisidora y comenzó el asombro del requerido don Quijote, el cual, dando un gran suspiro, dijo entre sí. « Que tengo de ser tan desdichado andante que no ha de haber doncella que de mí no se enamore! ¡Que tenga de ser tan corta de ventura la sin par Dulcinea del Toboso que no la han de dejar a solas gozar de la incomparable firmeza mía!»... 
Se consuma aquí uno de esos juegos y reversiones típicamente cervantinos. Si la ocasión del suspiro abortado estaba preñada de melancolía, el suspiro efectivo se produce ahora, en cambio, en un contexto plenamente paródico (pues es señal de imitación paródica que el viejo hidalgo se conceda a sí mismo la misma capacidad de seducción que los caballeros andantes manifestaban en las novelas de caballerías) ${ }^{17}$. Para cerrar la situación Cervantes hace que su protagonista concluya la escena con un gesto ampliamente teatral: $« Y$ con esto cerró de golpe la ventana y, despechado y pesaroso como si le hubiera acontecido alguna gran desgracia, se acostó en su lecho...». «Como si le hubiera acontecido alguna desgracia» significa que la desgracia, aunque no ha ocurrido objetivamente a nuestros ojos, sí que ha ocurrido en su ánimo, y en cualquier caso no nos cabe duda de que esa noche nuestro querido hidalgo, solitario y confundido en su aposento, está poseído por el oscuro demonio de la melancolía.

La comicidad de la escena no la vacía de emociones. Thomas Mann se sorprendía al experimentar cómo en el Quijote Cervantes lograba la configuración de un «pathos cómico» o de una «comicidad patética» (cfr. Koppen, 1990: 256). Pero esta anomalía se resuelve sin problemas en el alambique del humor, que no es pura y alegre comicidad, sino que tiene sus puntas de reflexión y de amargura y no excluye, sino que incluye, el sentimiento ${ }^{18}$. El comentado suspiro de don Quijote es una muestra paradigmática de ese humor cervantino: ese «gran suspiro» en la soledad de su cuarto es un signo profundo de emoción auténtica, y así nos llega también a nosotros, pero al mismo tiempo es inevitable que una sonrisa surja en el lector ante la ridícula tesitura de ese cincuentón que se agobia al pensar que todas las doncellas van detrás de su palmito.

\section{EL SUSPIRO LETAL DEL «ENAMORADO PORTUGUÉS»}

Sin salirnos de la órbita cervantina, el último suspiro que comentaremos es precisamente un «último suspiro», que aparece, por añadidura, en el último suspiro creativo del escritor alcalaíno: Los trabajos de Persiles y Sigismun$d a$. Lo encontraremos en uno de esos «relatos de vida» que son tan frecuentes en esta obra de carácter bizantino, sin duda oscurecida por la inmortal novela de Cervantes y por sus relatos ejemplares, pero que en muchos senti-

${ }^{17}$ La emisión del suspiro en un contexto claramente paródico se repetirá dos capítulos después, y entre los mismos personajes, cuando una Altisidora supuestamente despechada manifieste su vengativo deseo de que don Quijote no pueda nunca gozar de su amada Dulcinea: «A todo esto no respondió don Quijote otra palabra — escribe el narrador - si no fue dar un profundo suspiro, y luego se tendió en su lecho...» (II, 46, 1096).

${ }^{18}$ Para todo esto, remito de nuevo a mi libro (García Gibert, 1997: 55-64). 
dos mantiene intacta la capacidad de sugerencia y la marca de fábrica de su autor. El relato concreto al que nos referimos es, por lo demás, plenamente cervantino en su peculiar registro irónico-piadoso y en el tenor de su propio argumento esencial: el conflicto entre el amor divino y el humano, o la renuncia a este por causa de aquel. El mismo asunto ya lo había apuntado Cervantes en otras ocasiones (muy señaladamente en su novela corta La española inglesa) y late en el propio esquema intencional del Persiles, pues el rechazo al amor matrimonial por otro amor de índole religiosa es una tentación muy fuerte de Sigismunda, su protagonista femenina ${ }^{19}$.

La historia a la que nos referimos se narra en los capítulos 9 y 10 de la Primera Parte y es conocida como la historia de «el enamorado portugués», cuyo protagonista remite a un personaje bien conocido por aquellos años: Manuel de Sousa Coutinho. Se trata de un hidalgo portugués que compartió cautiverio argelino con Cervantes y que, ya maduro, acabó profesando en la orden dominica y convirtiéndose en un importante cronista de la época bajo el nombre de Fray Luis de Sousa. A Cervantes — como a otros escritores, que fabricaron sobre él leyendas diversas - le impactó mucho este personaje, al que ya alude en su temprana obra teatral Los tratos de Argel (v. 2365), y cuya vida aventurera le sugiere ahora una historia trágica y emocionante que es obviamente, a la vez que una suerte de homenaje, una completa sublimación literaria (hasta el punto de que la muerte de Manuel de Sousa, que narra el relato cervantino, no se produjo hasta 16 años después de la del propio Cervantes) ${ }^{20}$.

Pero vayamos ya a la sustancia del relato, tal como se presenta en la novela póstuma cervantina. Un grupo formado por los protagonistas Periandro (Persiles) y Auristela (Sigismunda) junto con otros compañeros de aventuras encuentra en su peregrinar por el Norte de Europa a un melancólico portugués cantando una triste canción. Esto les mueve a curiosidad y esa misma noche, al amor del fuego, el portugués accede a contarles su historia. Su nombre es Manuel de Sosa Coitiño y es un lisboeta de buena familia que desde niño estuvo enamorado de una vecina suya, Leonora, hermosa, rica y de noble linaje. Solicitada formalmente en matrimonio a sus padres, estos le piden que espere dos años porque la niña es demasiado joven para casarse. Manuel, de profesión militar, deja su patria para servir a su rey en Berbería, y vuelve ilusionado en el plazo previsto para casarse con Leonora, que ya está siendo solicitada por los principales nobles de dentro y de fuera de Portugal. Pero los

\footnotetext{
${ }^{19}$ Por lo demás, este era - y es - un asunto de gran predicamento en la novela de inspiración católica de todos los tiempos, desde la contrarreformista Selva de aventuras (1565) de Jerónimo de Contreras hasta la «moderna» La puerta estrecha (1909) de André Gide.

${ }^{20}$ Para la historicidad del personaje y su efectiva relación con el que aparece en el Persiles cervantino, así como sobre los elementos biográficos de Manuel de Sousa que pudieron inspirar a Cervantes para construir su relato, véase Roig (2004).
} 
padres de Leonora se muestran firmes en la promesa que le hicieron y le citan para una determinada fecha en un convento de monjas donde le entregarán la mano de su hija. Llegado el día, Manuel acude con toda su familia y amigos a la ceremonia, preparada con impresionante boato y en medio de una general expectación. Leonora está esperándole en mitad del templo, «tan bella, tan costosa, tan gallarda y tan ricamente compuesta y adornada, que causó envidia en las mujeres y admiración en los hombres». Manuel, embelesado, sube al altar — que está dispuesto, escribe Cervantes, a «modo de teatro»donde Leonora le espera y cae de rodillas ante ella para obtener su mano. Leonora le agradece la fidelidad de su amor y le confirma que ha cumplido la promesa que le hizo su padre de que «yo no tomaría otro esposo en la tierra sino a vos». Pero a renglón seguido proclama que no puede casarse, porque está ya casada... con Jesucristo: «Él es mi esposo; a Él le di la palabra primero que a vos (...) Yo confieso que para escoger esposo en la tierra ninguno os pudiera igualar, pero habiéndole de escoger en el cielo, ¿quién como Dios?». Recién acabado su discurso, las monjas comienzan a despojarla de sus lujosos vestidos y a cortarle los cabellos, en tanto que Manuel, confuso y aturdido, sólo acierta a besarle la mano. Ella entonces lo abraza «cristianamente compasiva», mientras él musita oportunamente una frase del Evangelio de San Lucas: Maria optimam partem elegit.

Continuamos aquí con el texto cervantino ${ }^{21}$ :

Y diciendo esto me bajé del teatro, y, acompañado de mis amigos, me volví a mi casa, adonde yendo y viniendo con la imaginación en este estraño suceso, vine casi a perder el juicio; y ahora por la misma causa vengo a perder la vida.

Y dando un gran suspiro, se le salió el alma, y dio consigo en el suelo.

El final del relato y el suspiro mortal del «enamorado portugués» se producen, pues, al unísono y sin solución de continuidad. Y el lector no deja de sentirse asombrado (como le pasa tantas veces con el escritor alcalaíno). Cervantes, en efecto, nos ha sorprendido, pero no porque haya rehuido las situaciones tópicas, sino porque las ha llevado hasta el extremo y las ha convertido en reales y efectivas. Por una parte, el tópico de los portugueses como seres tiernos y enamoradizos, constantemente repetido en la literatura de la época y del que el propio Cervantes se hace eco en algún otro lugar ${ }^{22}$. Con sarcasmo hablaba Quevedo en el Sueño de la muerte de esos «portugueses derretidos» que supuestamente morían de amor. Pues bien, Cervantes nos muestra a uno que verdaderamente lo ha hecho. Por otra parte, se lleva también a su literali-

\footnotetext{
${ }^{21}$ Empleamos la edición a cargo de J. B. Avalle-Arce (Cervantes, 1969).

${ }^{22}$ Cuando en el capítulo I del Libro Tercero del Persiles llegan los peregrinos a Lisboa, la tierra del «enamorado portugués», se encuentran con un vecino suyo que tuvo que dar la cruel noticia a sus parientes, que rápidamente la creyeron «por tener casi en costumbre el morir de amores los portugueses».
} 
dad absoluta otro tópico retórico de gran predicamento: el de los suspiros mortales. Podríamos mencionar infinidad de ejemplos, pero nos limitaremos sólo a un par de ellos, bien significativos. En la muy suspirante poesía amorosa de Fernando de Herrera hay un soneto (el XI) dedicado por entero a esos suspiros con sabor a muerte, que termina: «assí acabo la vida en el suspiro». Pero el poeta sigue amando y suspirando; se trataba, obviamente, de una muerte metafórica. Y lo mismo ocurre con suspiros que remiten a otro tipo de melancolías letales, que no se ceñían al ámbito amoroso. Ofelia relata a su padre Polonio un impactante suspiro de Hamlet presenciado por ella: «un suspiro tan profundo y lastimero que pareció destrozarle todo el cuerpo y acabar con su existencia ${ }^{23}$. Pero con Hamlet, como sabemos, no acabará este abismal y espectacular suspiro sino la emponzoñada espada de Laertes.

Sin embargo, el portugués enamorado sí que acaba su vida con ese suspiro, que verdaderamente ha sido, como suele decirse, su último aliento. Y entonces advertimos nosotros, como lectores, que no habíamos otorgado suficiente crédito a los repetidos anuncios del personaje que nos iban anticipando este trágico final, y que tomábamos como meras expresiones retóricas de dolor: en su primer cruce de palabras con Periandro («...porque las penas que siento en el alma me van dando señales de que tengo la vida en sus últimos términos»); al empezar la narración de su historia, cuando se refiere a «cierto sueño que la pasada noche me turbó el alma» porque le anunciaba oscuramente el fin de su vida; e incluso en el transcurso de su propio relato, en el que afirma no detenerse en ciertos detalles «porque a las puertas de mi vida está llamando la muerte». No hemos creído en el dolor literalmente mortal del enamorado portugués como tampoco lo creían sus escuchantes, que quedaron «confusos y admirados del triste y no imaginado suceso». Ellos habían pensado que, como tantas otras veces, con meras palabras consolatorias podrían alterar el curso fatal del corazón doliente. Esto le había dicho a Manuel de Sousa el protagonista de la obra al saber de su afligido estado de ánimo:

El alma ha de estar — dijo Periandro- el un pie en los labios y el otro en los dientes, si es que hablo con propiedad, y no ha de dejar de esperar su remedio, porque sería agraviar a Dios, que no puede ser agraviado, poniendo tasa y coto a sus infinitas misericordias.

Un gran poeta y crítico español, aunque reconocía que el fragmento «es de difícil y dudosa interpretación», entendía así estas palabras de Periandro: «Cuando nos encontramos en situación difícil y apurada, el alma del hombre debe estar con un pie en los labios para pedir a Dios ayuda, y con el otro pie en los dientes para esforzar el ánimo» (Rosales, 1985: 1007). Sin estar del todo en desacuerdo con el sentido último de esta lectura, creo, sin embargo, que, a

\footnotetext{
${ }^{23}$ «He raised a sigh so piteous and profound / as it did seem to shatter all his bulk / and end his being» (Acto II, vv. 94-95).
} 
los efectos de la perspectiva que adoptamos en este trabajo, podríamos precisar algo más el significado de estas palabras, en las que los «labios» parecen referirse a la expresión abierta de la dolorida queja y los «dientes» no son tanto un síntoma de esfuerzo (en el sentido popular de apretar los dientes) como una barrera de contención, y remiten a una viejísima metáfora homérica de larga repercusión en la literatura occidental. Ya la encontramos en la Ilíada (XIV, v. 83), donde Ulises reconviene a Agamenón de esta manera: «Hijo de Atreo, ¿qué palabra es esa que has dejado escapar del cerco de tus dientes?». Y la misma frase se repite hasta media docena de veces en la Odisea. Los comentaristas no han tenido duda en la interpretación de esta imagen homérica. En sus siempre interesantes Noches áticas (Libro I, cap. 15) Aulo Gelio aludía precisamente a la primera aparición de esta frase en la Odisea (I, vv. 64), confirmando su significado: que «la barrera de los dientes sirve para frenar las palabras impetuosas ${ }^{24}$. El propio Cervantes emplea otras veces esta misma imagen con este significado clásico de contención ${ }^{25}$, un significado que, por lo demás, haciendo honor a la referencia homérica, venía siendo habitual en la tradición humanística ${ }^{26}$.

Teniendo todo esto en cuenta, Manuel de Sosa Coitiño tiene, en efecto, «el un pie en los labios y el otro en los dientes» cuando nos relata su triste historia, pues, lleno de sentimiento, ha puesto su corazón en los labios cuando nos la cuenta, pero también ha puesto su freno en los dientes, evitando cualquier palabra inapropiada o cualquier queja que pudiera entenderse como un desmerecimiento de la santa elección de Leonora o de su preferencia por su «rival» (Cristo). Pero el caso es que él tenía ya, de hecho, como en otra ocasión dice el propio Cervantes de un supuesto moribundo, «el alma en los dientes» ${ }^{27}$, y

${ }^{24}$ Los modernos exégetas de Homero no se alejan de esta antigua interpretación, aunque a veces con un sentido algo más amplio. Jean Starobinski, por ejemplo, lo entendía como un signo necesario de control, discreción e introspección en los hombres fuertes: «Retener el aliento, impedirle huir para siempre más allá de la barrera de los dientes: forma elemental pero capital del control ejercido en los límites en que se separa un afuera y un adentro personales» (2000: 303).

${ }^{25}$ Desde la expresión sumaria «digo entre mis dientes» (en el sentido de decir o musitar para uno mismo, Cervantes, 2004: 185) hasta frases algo más largas, como aquella en la que Monipodio frena una discusión entre dos de sus secuaces con estas palabras: «No pase más adelante, caballeros; cesen aquí palabras mayores y desháganse entre los dientes» (Cervantes, 1980: 230)

${ }^{26}$ Muchas veces para subrayar la discreción y la sobriedad del sabio. Mencionemos sólo un ejemplo paradigmático: en un lugar de sus Ensayos (II, 2) Montaigne dice que el alma, «echando el freno a los dientes» («prenant le frein aux dents») debe actuar y llevar el hombre a lo más alto sin hacer vanas y retóricas declaraciones.

${ }^{27}$ Se refiere a Basilio, que, como sabemos, finge su muerte para casarse in articulo mortis con Quiteria. A este respecto dirá con gracia Sancho, al ver que el «moribundo» Basilio habla demasiado y no acaba de morirse: «Para estar tan herido este mancebo (...) mucho habla: háganle que se deje de requiebros y que atienda a su alma, que a mi parecer más la tiene en la lengua que en los dientes»(Cervantes, 2004, II: 21, 878 y 879). 
la barrera de esos dientes no ha podido evitar que el alma se le haya escapado en un suspiro. Aunque aquí Cervantes parece jugar con otro tópico de la literatura amorosa, que ya conocemos: el del suspiro como beso en ausencia del enamorado. Según leemos en el último capítulo de El Cortesano, cuando el amante platónico besa en la boca al amado no lo hace para unir sensualmente sus cuerpos físicos, sino para unir sus almas espiritualmente, y en esos besos de amor - dice Castiglione- le viene al enamorado «el alma a los dientes para salirle ya del cuerpo». Esto sería una imagen posible del último suspiro de Manuel de Sosa, tal como ha sido alguna vez interpretado por la crítica: «la ausencia de la otra boca que recibe y asimila el alma amada traduce la amarga soledad del enamorado, reforzando la tipología del personaje como representante de la muerte por amor no correspondido» (Mussons, 1999: 158).

Pero la historia del enamorado portugués tiene una coda inesperada y emocionante - la última de toda la serie de sorpresas e ironías que jalonan el relato $^{28}$ - , que el lector recibe casi cuarenta capítulos después, ya en la Tercera Parte del libro. Cuando, llegados a Portugal, los peregrinos pasan cerca de Lisboa no se olvidan de preguntar por la reacción de la monja Leonora al recibir la noticia del funesto fin de su enamorado: «dentro de pocos días que la supo —les informan-, pasó desta a mejor vida» (Cervantes, 1969, III: 1, 281). Todo parece indicar que el último suspiro de Manuel de Sosa llegó, aunque tarde y con letal efecto, a su destino, en una especie de figuración a distancia de la escena que cuenta Garcilaso cuando Venus recoge con su boca el último aliento del moribundo Adonis: «boca con boca coge la postrera / parte del aire que solía dar vida / al cuerpo por quien ella en este suelo / aborrecido tuvo al alto cielo» (Egloga III, vv. 189-192). Obviamente, la inmortal Venus no murió de amor como la mortal Leonora, que, por lo demás, no aborreció a los cielos por su amor humano, sino que, apartándolo, «se casó» con Cristo. Pero Cervantes en esta ocasión recoge valiente y discretamente (como de pasada) el triunfo del amor humano sobre el amor divino, incluso por encima de la voluntad explícita de la propia Leonora. Quizá no a su alma — que era de Cristo-, pero sí a las entrañas de su corazón sensible le llegó como un dardo mortal el alma que «se le salió» de entre los dientes al portugués enamorado con el «gran suspiro». Un suspiro largo que, tras matar al amado, ha alcanzado a la amada y que al cabo ensarta a Leonora y Manuel de Sosa en la larga y conmovedora lista de amantes malogrados que sólo se han unido más allá de la muerte.

${ }^{28}$ Todo el relato está transido de ironías narrativas: al describir la belleza en el templo de su inminente desposada, Manuel de Sosa siente que, aun «el emperador del mundo» sería «indigno de merecerla», afirma entusiasmado que Leonora en el altar «parecía la casta Diana», al morir se descubre por un escapulario que lleva colgado del pecho que el portugués es caballero de la Orden de Cristo (el «rival» que le ha desposeído de Leonora), etc., etc. 


\section{BIBLIOGRAFÍA CITADA}

Avilés, Luis F. (2003). «Los suspiros del Abencerraje», Hispanic Review. 71, otoño, pp. 453472.

Beszard, Lucien (1903). Les larmes dans l'épopée, particulièrement dans l'épopée française jusqu'à la fin du XIIe siècle; étude de littérature comparée. Halle sur Saale: E. Karras.

Cervantes Saavedra, Miguel de (1969): Los trabajos de Persiles y Sigismunda. J. B. Avalle Arce (ed.). Madrid: Castalia.

Cervantes Saavedra, Miguel de (1980): Rinconete y Cortadillo. Harry Sieber (ed.). Madrid: Cátedra.

Cervantes Saavedra, Miguel de (2004): El ingenioso hidalgo Don Quijote de la Mancha. Instituto Cervantes 1605-2005 (ed.); Rico, F. (dir.). Barcelona: Instituto Cervantes - Galaxia Gutenberg - Círculo de Lectores.

García Gibert, Javier (1997). Cervantes y la Melancolía. Ensayos sobre el tono y la actitud cervantinos. Valencia: Ediciones Alfonso el Magnánimo. Col. Novatores.

González Roldán, Aurora (2009). La poética del llanto en sor Juana Inés de la Cruz. Zaragoza: Ediciones de la Universidad.

Koppen, Erwin (1990). Thomas Mann y Don Quijote. Ensayos de literatura comparada. Barcelona: Gedisa.

Leclercq, Jean (2009). El amor a las letras y el deseo de Dios. Salamanca: Ediciones Sígueme.

López Estrada, Francisco (ed.) (1980). El Abencerraje. (Novela y romancero). Madrid: Cátedra.

Menéndez Pidal, Ramón (1951). «La Chanson des Saisnes en España», en Mélanges Mario Roques. I, pp. 229-44. Reeditado en 1956 en Los godos y la epopeya española. "Chanson de geste» y baladas nórdicas. Madrid: Espasa-Calpe.

Menéndez Pidal, Ramón (1973). «Estudios sobre el Romancero», en Obras completas de R. Menéndez Pidal, XI. Madrid: Espasa-Calpe.

Montaner, Aberto (ed.) (2011). Cantar de Mio Cid. Madrid: Ediciones de la Real Academia Española.

Mussons, María Rosa (1999). «Alma, aire, bocas. El beso de Auristela en el Persiles», Cervantes: Bulletin of the Cervantes Society of America. XIX, 2, pp. 154-166.

Rodríguez Puértolas, J. (ed.) (1992). Romancero. Madrid: Akal.

Roig, Adrien (2004). «De la vida de Manuel de Sousa Coutinho al "triste y no imaginado suceso" del portugués que murió de amor en el Persiles», en Alicia Villar Lecumberri (ed.), Peregrinamente Peregrinos. V Congreso Internacional de la Asociación de Cervantistas. Lisboa: Asociación de Cervantistas - Fundación Calouste Gulbenkian, pp. 881-898.

Rosales, Luis (1985). Cervantes y la libertad. Madrid: Ediciones Cultura Hispánica.

Serés, Guillermo (1996). La transformación de los amantes. Barcelona: Crítica.

Smith, Colin (1977). Estudios cidianos. Madrid: Cupsa.

Starobinski, Jean (2000). Remedio del mal. Madrid: A. Machado Libros.

Valencia, Felipe (2008). «"Acoged blandamente mi suspiro". El beso de almas en la poesía petrarquista española del siglo XVII», Dicenda. Cuadernos de Filología Hispánica. 28, pp. 259-295.

Fecha de recepción: 9 de junio de 2014.

Fecha de aceptación: 6 de noviembre de 2014. 